\title{
MODEL INTEGRACJI GOSPODARCZEJ JAKO WZORZEC SCALANIA SYSTEMÓW BIZNESOWYCH - KONCEPCJA I JEJ INTERPRETACJA (NA WYBRANYCH PRZYKLADACH)
}

\begin{abstract}
Streszczenie. Celem artykułu jest prezentacja koncepcji modelu integracji biznesowej, wzorowanej na klasycznym modelu integracji B. Balassy. W początkowej części opracowania starano się wykazać, że mechanizm integracji jest niezależny od typu obiektu. Działania integracyjne stanowią bowiem sposób dostosowań do wymogów zmieniającego się otoczenia - wyzwań globalizacji i liberalizacji. W kolejnej części przedstawiono koncepcję sześcioetapowego modelu integracji biznesowej. W ostatniej części opracowania (podzielonej na uwagi teoretyczne oraz case studies) podjęto próbę egzemplifikacji modelu na przykładach scalania systemów biznesowych korporacji transnarodowych.
\end{abstract}

Słowa kluczowe: integracja, integracja biznesowa, globalizacja, korporacje, systemy biznesowe.

\section{WPROWADZENIE}

We współczesnej dynamicznie zmieniającej się gospodarce wszyscy uczestnicy rynku poszukują inspiracji i wzorców, które pozwoliłyby im poprawić swoją pozycję, usprawnić zarządzanie tak, aby najlepiej wykorzystać nowe szanse i odeprzeć ewentualne zagrożenia. Wydaje się, że bez względu na to, czy mamy do czynienia z państwem czy przedsiębiorstwem, tak właśnie można zdefiniować istotę strategii rozwojowej. Wszystkie typy uczestników rynku dostrzegają też, że zmiany zachodzące w otoczeniu gospodarczym, określane zwykle mianem globalizacji i liberalizacji, stanowią z pewnością wyzwanie, któremu coraz trudniej sprostać pojedynczym podmiotom, stąd intensyfikacja szeroko pojętych procesów integracyjnych. W literaturze dość powszechnie uznaje się model integracji gospodarczej państw - oznaczający przechodzenie od umów preferencyjnych do strefy wolnego handlu, poprzez unię celną, wspólny rynek, unię gospodarczą, unię walutową do pełnej integracji - za swoisty wzorzec etapowej ewolucji integrujących się podmiotów.

* Uniwersytet Łódzki, Wydział Ekonomiczno-Socjologiczny, Katedra Międzynarodowych Stosunków Gospodarczych. 
Celem niniejszego opracowania jest przedstawienie koncepcji modelu integracji biznesowej, wzorowanego na klasycznym modelu B. Balassy, jako formy schematu rozwojowego, który wykorzystywany jest nie tylko przez państwa, lecz także inne podmioty - przedsiębiorstwa międzynarodowe. Podjęto próbę wykazania, że mimo różnic związanych z obszarem branżowym czy krajem pochodzenia istota budowania powiązań pozostaje niezmienna - poprawa efektywności funkcjonowania w dynamicznie zmieniających się warunkach (postępującej globalizacji i liberalizacji).

Na początku artykułu starano się wykazać, że działania podmiotów (państw, przedsiębiorstw, jednostek) służące rozwijaniu systemu wielostronnych powiązań stanowią realizację procesu integracji, którego logika - niezależnie od obiektu go realizującego - jest identyczna. Działania te stanowią bowiem wyraz dostosowania do wymogów zmieniającego się otoczenia - odpowiedź uczestników rynku na wyzwania ewoluującej globalizacji i postępującej liberalizacji rynków. W kolejnej części przedstawiono koncepcję modelu integracji biznesowej, uwzględniając genezę koncepcji, ideę przyświecającą jej stworzeniu oraz omawiając poszczególne elementy sześcioetapowego modelu. W końcowej części opracowania (podzielonej na uwagi teoretyczne oraz case studies) podjęto próbę egzemplifikacji modelu integracji biznesowej z wykorzystaniem historii rozwoju przedsiębiorstw międzynarodowych - korporacji transnarodowych pochodzących z różnych krajów i działających w odmiennych sektorach. Starano się w ten sposób wykazać, że przedstawiony model można uznać za swoisty wzorzec scalania systemów biznesowych na bazie klasycznego modelu integracji gospodarczej.

\section{POGŁĘBIANIE PROCESU INTEGRACJI JAKO ODPOWIEDŹ UCZESTNIKÓW RYNKU NA WYZWANIA GLOBALIZACJI I LIBERALIZACJI}

W tej części artykułu starano się zwrócić uwagę, że podjęcie trudu integracji (zarówno przez państwa, jak i przedsiębiorstwa) stanowi wynik poszukiwania coraz lepszych metod dostosowywania się wszystkich uczestników rynku do nowych wyzwań. To zmiany w gospodarcze światowej spowodowały konieczność przewartościowań dotychczasowych modeli rozwojowych. Postępujący proces liberalizacji przepływów gospodarczych wraz z pogłębiającym się i rozwijającym procesem globalizacji rodzą bowiem nowe wyzwania. Na rys. 1 starano się zobrazować istotę dokonujących się systematycznie zmian - przez pryzmat ewolucji procesów globalizacji w powiązaniu z ponadnarodowym regulacjami na forum GATT/WTO, które miały istotny wpływ na zakres liberalizacji handlu światowego oraz przepływów kapitałowych.

W przedstawionym modelu przyjęto, że zasadniczym przejawem globalizacji jest przeniesienie odpowiedzialności za tworzenie uwarunkowań rozwoju z państw narodowych na ponadnarodowe podmioty i instytucje. Globalizacja to 
proces składający się z ciągu procesów (Scholte 2000: 43-56), coraz ściślejszej integracji państw i ludzi w skali globu, który został spowodowany ogromną redukcją kosztów transportu i telekomunikacji oraz zniesieniem sztucznych barier w przepływach dóbr, usług, kapitału czy wiedzy (Stigliz 2004: 26). Towarzyszy jej tworzenie nowych form organizacji (instytucji), które stale prowadzą swoją działalność przekraczając granice pojedynczych państw (organizacje międzynarodowe, ugrupowania integracyjne, globalne sieci biznesowe) i funkcjonują jako centra stymulujące rozwój gospodarki światowej - będąc źródłami impulsów rozwojowych dla konkretnych sfer (politycznych, gospodarczych, branżowych, społecznych etc.). Istotne znaczenie dla niniejszych rozważań ma zaakcentowanie faktu, iż postępująca liberalizacja i globalizacja tworzą systematycznie coraz to nowe uwarunkowania rozwojowe - nowe wymogi dla uczestników rynku (państw, przedsiębiorstw, jednostek).

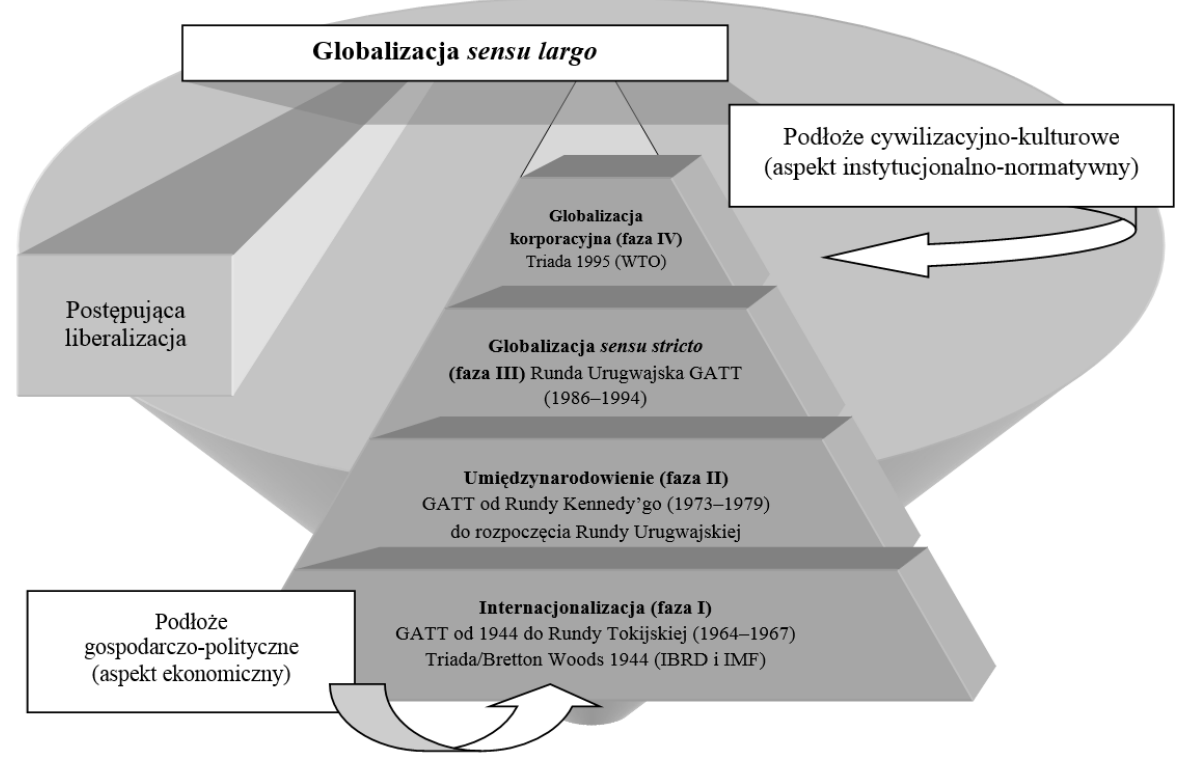

Rys. 1. Fazy rozwoju procesów globalizacyjnych a decyzje na forum GATT/WTO

Źródło: opracowanie własne.

Globalizacja sensu largo to ogół zmian związanych z percepcją gospodarki światowej po II wojnie światowej i ukształtowaniem modelu Triady (Budnikowski 2006: 17-21). Rozwijała się ona systematycznie, przechodząc kolejne fazy. Za osiągnięcie etapu globalizacji sensu stricto uznano dopiero moment zmiany percepcji uwarunkowań rozwojowych poprzez dostrzeżenie wzrostu znaczenia 
usług, inwestycji zagranicznych oraz własności intelektualnej jako determinant przewagi konkurencyjnej ${ }^{1}$. Wejście w fazę globalizacji korporacyjnej (Marzęda 2007: 31-39) - obecnie trwający etap - powiązano z modyfikacją układu sił ,starej"2 Triady (Flejterski, Wahl 2003: 220) na skutek wzrostu znaczenia systemów zintegrowanych, czyli współpracy, a zatem zdolności integracyjnych jako miary siły i potencjału rozwojowego danego uczestnika rynku międzynarodowego.

Na potrzeby niniejszego opracowania globalizację zdefiniowano zatem jako etapowy proces liberalizacji przepływów towarów, usług, kapitału ludzkiego i finansowego, zmierzający do stworzenia zintegrowanej, globalnej przestrzeni opartej na korporacyjnym ładzie instytucjonalnym, dzięki któremu możliwe staje się funkcjonowanie w złożonej sieci powiązań (Rosińska-Bukowska 2012: 40). Etapy rozwoju globalizacji zinterpretowano następująco:

- faza I (internacjonalizacja) - dominacja relacji o charakterze bilateralnym (ciągi takich transakcji), nieregularnym, głównie ,poszukujące” działania eksportowe (Wiedersheim-Paul, Olson, Welch 1978: 47-58); współpraca na podstawie teorii przewag względnych (korzyści lokalizacyjne, odmienność ofert); motywem jest wzrost korzyści skali; istotne znaczenie przy wyborze strategii rozwoju mają decyzje władz państwowych, np. preferencyjne umowy handlowe;

- faza II (umiędzynarodowienie) - jej początek to moment, w którym na znaczną skalę następuje przenoszenie czynników produkcji (zwłaszcza kapitałów) między gospodarkami; uznanie, że budowanie regularnych i trwałych relacji na rynkach zagranicznych to konieczność rozwojowa (Blomstermo, Sharma 2003: 262-263); kluczowe jest zdobycie „terytorium” - przewaga konkurencyjna w konkretnym obszarze rynku; porozumienia podmiotów o zbliżonym poziomie rozwoju, w obszarze bliskim geograficznie, kulturowo - bazowanie na względnie uniwersalnym charakterze potrzeb (,segmenty rynku” o zbliżonych preferencjach);

- faza III (globalizacja sensu stricto) - oligopolizacja poszczególnych sektorów i polaryzacja uczestników wokół liderów; przewagę zyskują podmioty rozumiejące istotę nowych wymogów (w tym znaczenie procesów integracyjnych);

- faza IV (globalizacja korporacyjna) - zjawiska napędzające globalizację eskalują wśród podmiotów gospodarczych dążenia do koncentracji (Gorynia, Jankowska 2008: 33); „,korporacyjność” odgrywa kluczową rolę w budowaniu przewagi, oznacza ,wyższość” działania wspólnego nad indywidualnym; kapitalne znaczenie dla rozwoju ma zdolność kreacji sieci powiązań (Gulati, Nohria, Zaheer 2000: 203-215), umiejętność funkcjonowania w układzie zintegrowanym.

${ }^{1}$ Podjęcie rokowań na poziomie ponadnarodowym (1986-1994) - Runda Urugwajska GATT.

2 Dla podkreślenia dokonujących się zmian wprowadza się nawet zamiast pojęcia „Triada” (USA, EWG, Japonia) pojęcia: „Pentada” (UE, NAFTA, Japonia z Azją Płd.-Wsch., Chiny, Rosja) lub „Sekstada” (poszerzenie o Indie). 
Podsumowując można stwierdzić, że współczesna globalizacja sensu stricto rozpoczęła się w momencie, kiedy o sukcesie (państwa, przedsiębiorstwa) zaczęły decydować zdolności integracyjne, pozwalające na rozwijanie działalności w skali globalnej (wyjście poza zamknięte, regionalne strefy wpływów), dzięki uruchomieniu powiązań poziomych i pionowych w celu zbudowania przewagi o charakterze systemowym (Esser et al. 1995: 143-148). Wymagało to zrozumienia istoty funkcjonowania organizacji (państwa, przedsiębiorstwa) w oparciu o wielowarstwowy system, bazujący na połączeniu wiedzy profesjonalnej, umiejętności praktycznej jej implementacji w zróżnicowanych warunkach oraz kompetencji holistycznego postrzegania wyzwań i szans rozwojowych. Innymi słowy, postępującą globalizacja wymusiła systematyczną integrację jako sposób lepszej eksploracji globalnej przestrzeni (rozwijania wiedzy i dodawania coraz nowych wartości do wcześniej realizowanego standardu), a nie tylko bazowania na eksploatacji posiadanych zasobów (wyczerpywanych i ograniczonych). W tym ujęciu integracja stanowi mechanizm wzbogacania organizacji, źródło jej dodatkowych sił rozwojowych, pozwala na nadążanie za rosnącymi wymogami rynku globalnego (Platonoff 2009: 16-17). Ma przyczynić się do przeniesienia punktu ciężkości z eksploatowania dotychczas posiadanej przez nią wiedzy i zasobów na kreację wartości dodanej - nowych walorów, dzięki nowym i/lub rozwijanym powiązaniom. Pogłębianie procesu integracji można zatem traktować jako odpowiedź uczestników rynku na wyzwania globalizacji.

\section{KONCEPCJA MODELU INTEGRACJI BIZNESOWEJ - GENEZA, IDEA, ELEMENTY}

W tej części opracowania podjęto próbę wykazania, że proces integracji stanowi ciąg zdarzeń wykazujących pewne cechy wspólne w poszczególnych fazach jego zaawansowania. Dodatkowo, ewolucja zakresu integracji ma podobny charakter niezależnie do typu obiektów realizujących ten proces. Analizując rozwój najpotężniejszych korporacji transnarodowych, dostrzeżono pewne podobieństwa ich ścieżek rozwojowych, mimo ulokowania w różnych sektorach i legitymowania sie różnym pochodzeniem (krajem macierzystym), a także zbieżność tego modelu z koncepcją integracji państw. Wydaje się zatem, że jest to realizacja pewnego spójnego, względnie uniwersalnego planu rozwojowego. Istotę tego planu stanowi systematyczność i etapowość. Jego efektem natomiast jest rosnący stopień intensyfikacji systemu powiązań. W konsekwencji, bazując na znanym i powszechnie akceptowanym modelu, podjęto próbę ,przypisania” kolejnym fazom procesu integracyjnego (opisywanego dla państw) adekwatnych zachowań podmiotów gospodarczych (przedsiębiorstw).

Założeniem modelu jest - poprzez wykorzystanie idei/filozofii poszczególnych etapów integracji regionalnej - spowodowanie niejako automatycznego 
przenoszenia schematów postrzegania zachowań podmiotów jako charakterystycznych i oczekiwanych dla danego stopnia ich zespolenia między sobą. Wykorzystanie wzorca sekwencyjnego przebiegu procesów integracyjnych, zachowanie układu etapów, zdefiniowanie ich na bazie cech modelu klasycznego ma ułatwić obserwację zachowań integrujących się członków systemu, a nawet pozwolić na przewidywanie ich kolejnych posunięć. Ponadto przyjmując, że przedsiębiorstwa realizują kolejne etapy rozwoju zgodnie z logiką modelu integracji, można próbować ustalić „dojrzałość organizacyjną” danego systemu biznesowego/korporacji - dokonać oceny stopnia zaawansowania procesów rozwojowych, co może z kolei stanowić podstawę wskazywania bezpośrednich konkurentów (reprezentujących ten sam poziom, stosujących zbieżne metody ekspansji, instrumenty konkurowania etc.).

Schemat działań przedsiębiorstw, które można uznać za oddające istotę zmian dokonywanych przy integracji państw narodowych, przedstawiono w tab. 1. Ideą modelu jest ustalenie sekwencji działań przedsiębiorstw, która pozwoli na ocenę pozycji rynkowej podmiotu na podstawie posiadanych zdolności konkurencyjnych, kooperacyjnych i kooperencyjnych ${ }^{3}$ oraz organizacyjnych i zarządczych, pozwalających na coraz efektywniejsze działanie w globalnej przestrzeni.

Model integracji biznesowej, przedstawiony w tab. 1, skonstruowano posługując się sześcioetapowym modelem budowania jednolitego organizmu gospodarczo-politycznego ${ }^{4}$. Każdy kolejny etap integracji oznacza osiągnięcie wyższego poziomu zaawansowania organizacyjnego, co świadczy o udoskonaleniu modelu zdobywania wiedzy, umiejętności i rozwijaniu kompetencji danego podmiotu. W konsekwencji przedsiębiorstwa, którym udało się „dotrzeć na szczyt” tej systematycznie nadbudowywanej piramidy to te, które stworzyły sprawnie funkcjonujący system powiązań nie tylko biznesowych. Osiągnięcie etapu „unii gospodarczej”, ,unii walutowej”, a tym bardziej „unii politycznej” wymaga bowiem ustanowienia wielowymiarowych relacji z multikulturowym otoczeniem globalnym. Oznacza to, że wykreowany system biznesowy musi być silnie zakorzeniony także w sferach pozaekonomicznych, gdyż bez rozpoznania i zrozumienia specyfiki „lokalnych” uwarunkowań społeczno-kulturowych nie byłby zdolny przetrwać. Glokalność struktur „unii politycznej”, rozumiana jako działalność o charakterze globalnym z uwzględnieniem różnic między rynkami lokalnymi oraz budowanie w oparciu o nie przewagi konkurencyjnej (Robertson 1985;

${ }^{3}$ Kooperencja to sytuacja, w której rywale konkurują w pewnych obszarach, ale w innych są zdolni do współdziałania (dzielenia się wiedzą, wymiany doświadczeń). Wymaga to poczucia własnej siły (kluczowych kompetencji) i „mądrości” wynikającej z dogłębnego zbadania wymogów współczesnego rynku (konieczności budowania konkurencyjności systemowej).

${ }^{4}$ Oczywiście należy od razu zaznaczyć, iż jest to upraszczający skrót myślowy. Służy on podkreśleniu, że powstały w efekcie tego procesu organizm będzie posiadał „,ponadnarodowe” instytucje (nie tylko gospodarcze, ale i polityczne), jednak nie oznacza to utraty suwerenności przez elementy składowe. 
Model integracji biznesowej - etapy integracji państw a rozwój systemu powiązań przedsiębiorstw

\begin{tabular}{|c|c|c|}
\hline Etap & $\begin{array}{l}\text { Opis etapu w modelu integracji } \\
\text { gospodarczej państw }\end{array}$ & $\begin{array}{l}\text { Opis etapu w modelu integracji } \\
\text { biznesowej przedsiębiorstw }\end{array}$ \\
\hline 1 & 2 & 3 \\
\hline I & $\begin{array}{l}\text { SWH (strefa wolnego handlu): } \\
\text { - zniesienie taryf i ograniczeń ilościo- } \\
\text { wych między państwami członkowskimi } \\
\text { strefy, } \\
\text { - lączenie podmiotów, zwykle o (ograni- } \\
\text { czonym „psychologicznym” dystansie) } \\
\text { zasięgu regionalnym, } \\
\text { - handel dobrami zróżnicowanymi (o „na- } \\
\text { rodowych” charakterystykach) }\end{array}$ & $\begin{array}{l}\text { Umowy o współpracy - zwykle w ramach } \\
\text { lańcucha produkcyjnego: } \\
\text { - zróżnicowana oferta produktowa pod- } \\
\text { miotów współpracujących, } \\
\text { - współpraca małych przedsiębiorstw kra- } \\
\text { jowych; aglomeracja - dystrykty prze- } \\
\text { mysłowe, } \\
\text { - ekspansja przedsiębiorstw poprzez usta- } \\
\text { nawianie oddziałów, zwykle o zasięgu } \\
\text { regionalnym }\end{array}$ \\
\hline II & $\begin{array}{l}\text { UC (unia celna): } \\
\text { - SWH + wspólna zewnętrzna taryfa celna: } \\
\text { - jednolita polityka wobec krajów } \\
\text { trzecich, } \\
\text { - wspólne zawieranie umów z parterami } \\
\text { zewnętrznymi, } \\
\text { - dominujące powiązania o charakte- } \\
\text { rze regionalnym }\end{array}$ & $\begin{array}{l}\text { Stała kooperacja przedsiębiorstw krajo- } \\
\text { wych prowadzi do ich konsolidacji: } \\
\text { - „monopolizacja narodowa” (małe kraje) } \\
\text { lub „oligopolizacja narodowa” (duże ob- } \\
\text { szary, np. USA czy UE), } \\
\text { - wspólne przedsięwzięcia - zawieranie } \\
\text { umów joint venture z podmiotami z wła- } \\
\text { snej branży, zwykle na bliskich kultu- } \\
\text { rowo i geograficznie rynkach (wspólne } \\
\text { wzorce konsumpcyjne) }\end{array}$ \\
\hline III & $\begin{array}{l}\text { WR (wspólny rynek): } \\
\text { - obszar bez granic wewnętrznych, } \\
\text { - oparty na czterech swobodach: } \\
\text { - przepływu towarów, } \\
\text { - przepływu usług, } \\
\text { - przepływu sily roboczej, } \\
\text { - przepływu kapitału }\end{array}$ & $\begin{array}{l}\text { Jednolita polityka handlowa produktu } \\
\text { (klasy produktów, segmenty rynku) - spe- } \\
\text { cjalizacja: } \\
\text { - ukształtowanie wiodących działów sieci } \\
\text { - konsolidacja sfer aktywności w kilku } \\
\text { obszarach (zwykle 2-5), } \\
\text { - stabilizacja i intensyfikacja powiązań } \\
\text { w tych sferach (produkcja, dystrybucja, } \\
\text { przepływ technologii, kapitału i zasobów } \\
\text { ludzkich), } \\
\text { - ustanawianie czterech typów filii (pro- } \\
\text { dukcyjnych, handlowo-usługowych, } \\
\text { technologicznych, strategicznych) }\end{array}$ \\
\hline IV & $\begin{array}{l}\text { UE (unia ekonomiczna): } \\
\text { - WR + koordynacja polityk gospodar- } \\
\text { czych uczestników, w tym np. polityki } \\
\text { konkurencji; } \\
\text { - ponadnarodowe instytucje zarządzają- } \\
\text { co-koordynujące }\end{array}$ & $\begin{array}{l}\text { Globalna koordynacja systemu: } \\
\text { - alianse strategiczne, intensyfikacja fuzji } \\
\text { i przejęć międzynarodowych (M\&As), } \\
\text { - wyłanianie strategicznych komórek or- } \\
\text { ganizacyjnych, nastawionych na koordy- } \\
\text { nowane globalnie rozproszonych funkcji; } \\
\text { centra kompetencji sieci }\end{array}$ \\
\hline
\end{tabular}


Tab. 1 (cd.)

\begin{tabular}{|c|c|c|}
\hline 1 & 2 & 3 \\
\hline V & $\begin{array}{l}\text { UW (unia walutowa): } \\
\text { - usztywnienie kursów wymiany walut, } \\
\text { - możliwa wspólna waluta, } \\
\text { - stopniowe ujednolicanie rynku kapita- } \\
\text { łowego, } \\
\text { - konieczność zmian instytucjonalnych } \\
\text { w wyniku pogłębienia integracji }\end{array}$ & $\begin{array}{l}\text { Portfel marek/marka globalna - seg- } \\
\text { menty rynku globalnego: } \\
\text { - ustalenie portfela marek z podziałem na } \\
\text { obsługiwane segmenty rynku (pozycjo- } \\
\text { nowanie marek - produktów), } \\
\text { - możliwe stworzenie wspólnej marki } \\
\text { (na bazie niegdyś samodzielnych) lub } \\
\text { „wciągnięcie” ich pod parasol wspólnej } \\
\text { marki, } \\
\text { - systematyczne ujednolicanie standardu } \\
\text { obsługi klienta globalnego - konkuro- } \\
\text { wanie „miękką” wartością dodaną, } \\
\text { - reorganizacja struktury zarządzania } \\
\text { w wyniku implementacji nowej strategii } \\
\text { konkurencyjnej }\end{array}$ \\
\hline VI & $\begin{array}{l}\text { UP (unia polityczna): } \\
\text { - ponadnarodowe instytucje - przenie- } \\
\text { sienie na poziom ponadnarodowy decy- } \\
\text { zji o charakterze ,politycznym”, } \\
\text { - pewien stopień dobrowolnego ograni- } \\
\text { czenia suwerenności nadal samodziel- } \\
\text { nych państw, } \\
\text { - wspólne stanowiska (kompromis) jako } \\
\text { wyraz współpracy konkurujących (na- } \\
\text { wet stale państw) walczących o pozycję } \\
\text { dominującą, przy rozwiązywaniu pro- } \\
\text { blemów globalnych } \\
\text { - kooperencja }\end{array}$ & $\begin{array}{l}\text { Globalne Sieci Biznesowe (GSB) jako } \\
\text { mechanizm regulacji - system „gospo- } \\
\text { darczo-polityczny”: } \\
\text { - globalny „zarząd” sieci, skupiającej } \\
\text { „zewnętrznie” samodzielne podmioty } \\
\text { - orchestrator* jako lider, koordynator } \\
\text { i dyrygent sieci**, } \\
\text { - ukształtowane obszary kluczowych } \\
\text { kompetencji, } \\
\text { - oligopole branżowo-regionalne, } \\
\text { - koncepcja współpracy na bazie strate- } \\
\text { giczne zorientowanego łańcucha two- } \\
\text { rzenia wartości, } \\
\text { - kooperencja - współpraca bezpośred- } \\
\text { nich konkurentów, } \\
\text { - uczestnictwo w przedsięwzięciach, po- } \\
\text { twierdzających „społeczną odpowie- } \\
\text { dzialność” organizacji }\end{array}$ \\
\hline
\end{tabular}

* Pojęcie process orchestrator wprowadzili J. Hagel i J. S. Brown; podobną interpretację przedstawili V. K. Fung, W. K. Fung, Y. Wind.

** Paradygmat przedsiębiorczości według H. H. Stevensona omawia trzy formy postaw: promotora, menedżera i zarządcy.

Źródło: opracowanie własne. 
Huff et al. 2011: 281-286) stanowi współcześnie fundament rozwoju wszystkich typów podmiotów. Zarządzanie tak skonstruowanym systemem gospodarczo-politycznym opiera się na zrozumieniu teorii regulacji ${ }^{5}$, czyli dostrzeżeniu odmienności modelu od tradycyjnego zarządzania (przedsiębiorstwem) - jest to swoisty model „zarządzania publicznego”, w którym konieczna jest partycypacja uczestników (interesariuszy) w procesie wyznaczania celów, kreowania misji organizacji i zasad jej działania. Współtworzenie modelu rozwojowego z wykorzystaniem wielu zróżnicowanych grup interesariuszy, $\mathrm{z}$ czym mamy do czynienia w tak zaawansowanej organizacji, jak globalna sieć biznesowa (GSB), predestynuje tego typu systemy do miana podmiotów sfery makroekonomicznej (może nie równych państwom, lecz z pewnością wykazujących pewne cechy im właściwe).

\section{INTERPRETACJA MODELU INTEGRACJI BIZNESOWEJ - UJĘCIE TEORETYCZNE}

Stawiając tezę, że nie tylko państwa, lecz także przedsiębiorstwa działają zgodnie z logiką mechanizmu integracji gospodarczej, podjęto próbę egzemplifikacji. Wykorzystując rankingi międzynarodowe, klasyfikujące najpotężniejsze przedsiębiorstwa na świecie (m.in. World Investment Report, Forbes, Fortune), badaniu poddano ich modele rozwojowe w perspektywie retrospektywnej - starając się podzielić historię budowania danego systemu biznesowego (obecnie stanowiącego jedną z wiodących korporacji transnarodowych) na fazy, zgodne z opisaną koncepcją integracji biznesowej. Przeprowadzona analiza rozwoju kilkuset najpotężniejszych korporacji transnarodowych ${ }^{6}$ wykazała, że wdrażany etapowy model budowania swoich sieci wpływów przez przedsiębiorstwa jest zbliżony do klasycznej koncepcji integracji gospodarczej państw. Korporacje transnarodowe w celu poprawy swojej pozycji konkurencyjnej w globalnej przestrzeni podejmują się bowiem tworzenia różnorodnych systemów powiązań, zacieśniania wybranych obszarów współpracy, modyfikacji swoich modeli zarząazzania w taki sposób, aby „ogarnąć” zbudowany system biznesowy o zasięgu ponadnarodowym (finalnie najczęściej globalnym). Na podstawie przeprowadzonych analiz zauważono pewne względnie uniwersalne prawidłowości.

Wstępna integracja ma zwykle charakter luźniejszych związków, skoncentrowanych na sferze branżowej aktywności przedsiębiorstwa, poczynając od najbliższego, lokalnego otoczenia. Najniższy etap integracji biznesowej stanowi w tym rozumieniu dystrykt marshallowski (Pyke, Sengenberger 1992: 3-4)

\footnotetext{
${ }^{5}$ Trzy możliwe modele regulacji to: rynki (konkurencja), hierarchie (kooperacja) i sieci (forma pośrednia, kooperencja).

${ }^{6}$ Badanie przeprowadzono, analizując modele rozwojowe ponad 200 KTN sklasyfikowanych w World Investment Report z lat 1990-2011.
} 
- odpowiednik preferencyjnego obszaru handlu lub strefy wolnego handlu. Klaster porterowski (Porter 1998; 2001: 246-302) to odpowiednik unii celnej. Kolejne, bardziej zaawansowane formy klastrów (Mikołajczyk, Kurczewska, Fila 2009: 26-27; Skawińska, Zalewski 2009: 19) należy traktować jako zalążki wspólnego rynku. Zwykle nie spełniają one jeszcze wszystkich założeń jednolitego rynku wewnętrznego, gdyż realizują tylko niektóre formy swobód. Sieć jako etap integracji biznesowej zostaje ulokowana powyżej, gdyż zakres i zasięg operacji wykonywanych wspólnie i/lub w porozumieniu z innymi członkami systemu obejmuje zwykle wszystkie sfery - model pełnego wspólnego rynku. Niektóre typy sieci mogą przybierać formy bardziej zaawansowane, np. budowanie sieci wokół jednej wspólnej marki - co zestawiono z realizacją koncepcji unii walutowej. Najwyższym etapem tak przedstawionej sekwencji integracyjnej jest globalna sieć biznesowa (GSB) - mechanizm regulacyjny o cechach etapu unii ekonomiczno-walutowej z elementami unii politycznej.

Poszczególne działania przedsiębiorstw starano się zatem zinterpretować jako „odpowiedniki” poszczególnych faz procesu integracji gospodarczej państw, tak aby oddawały istotę zacieśniania relacji między uczestnikami.

Integrację biznesową rozpoczyna zatem zbliżanie się obiektów ulokowanych „regionalnie”, czyli w przypadku procesów biznesowych w tej samej branży i tym samym regionie - mniejsze podmioty decydują się na współpracę, aby w efekcie aglomeracji poprawić swoją pozycję konkurencyjną. Pojawiają się dwustronne i wielostronne porozumienia o współpracy, dotyczące danej grupy podmiotów (usytuowanych zwykle wzdłuż łańcucha produkcyjnego), oznaczające wzajemne preferencyjne traktowanie, które nie wyklucza samodzielnego decydowania przez każdy z nich o zasadach budowania stosunków z innymi, nienależącymi do syste$\mathrm{mu}-$ jest to idea strefy wolnego handlu. W toku rozwoju procesów integracyjnych zacieśnianie więzi uzewnętrznia się tworzeniem wspólnych zasad realizacji transakcji z podmiotami zewnętrznymi oraz pewnym ujednolicaniem struktur.

Postępująca aglomeracja uczestników oznacza reorganizację i wyłanianie się podmiotów (często „nowych” - zmiana nazwy) zdolnych do ekspansji na rynek międzynarodowy, a przede wszystkim identyfikowalnych na tym rynku jako system zintegrowany - idea unii celnej. Powiększanie udziałów w „lokalnym” (narodowym, regionalnym) rynku branżowym pozwala uzyskać pozycję narodowego/ regionalnego oligopolisty. Silne na swoich rynkach podmioty podejmują nowe wyzwania - następuje ekspansja międzynarodowa o coraz większym zasięgu poprzez własne filie lub joint venture z partnerami lokalnymi. Internacjonalizacja to początkowo eksport ,sieciowych" produktów na najbliższe geograficznie i kulturowo rynki - o „niskim dystansie psychologicznym” (Håkansson, Snehota 1995: 24-49).

Stopniowo, gdy wyczerpują się efekty strefy wolnego handlu i unii celnej, bazujące na rozwoju handlu, następuje intensyfikacja interakcji z miejscami ekspansji - tworzenia wspólnych zasad działalności w celu poprawy spójności $\mathrm{z}$ wymogami miejsc lokalizacji (policentryzm). Zakres joint venture wskazuje 
obszary, w których dany partner może specjalizować się, wchodząc do zintegrowanych struktur sieci. Następnym etapem jest łączenie jednostek w spójne struktury regionalne i produktowe. „Regiocentryzm” ma dwa wymiary: geograficzny (układ struktur zarządzania globalnie rozproszoną aktywnością podmiotu) oraz produkcyjny (wskazujący kluczowe obszary kompetencji podmiotu - działy produktowe).

Należy zaznaczyć, że międzynarodowa ekspansja nie oznacza jednorodnych zachowań wszystkich typów przedsiębiorstw. Schemat postępowania może być różny, w zależności np. od specyfiki regionu inwestycji czy wizji rozwojowej danego podmiotu. Można tu przywołać klasyfikację J. Coopera, który wyróżnił pięć typów zachowań opisujących zasady współpracy korporacji z lokalnymi partnerami (Gorynia, Jankowska 2008: 179-181):

- najeźdźcy - np. montownie, szwalnie etc. wykorzystujące tanią siłę roboczą,

- osadnicy - próba uzyskania pozycji autochtona, a równocześnie zachowanie związków z rynkiem globalnym (np. Opel w ramach General Motors),

- klony - tworzenie „klonów” firmy-matki na rynkach lokalnych (np. Coca-Cola),

- baronowie - koncentracja na określonym rynku lokalnym produkcji i zaopatrzenia oraz globalna dystrybucja produktów (np. BMW),

- nieosiągalni - produkcja wyłącznie w jednym regionie świata, ale globalne zaopatrzenie i sprzedaż (np. Boeing).

We wszystkich typach relacji można zaobserwować, że wraz z „,dojrzewaniem" współpracy umowy dotyczą coraz szerokiego zakresu regulacji: towarów (produkcji), usług (handlu i usług z nim związanych), kapitału (finansowania realizowanych wspólnie przedsięwzięć) oraz siły roboczej (przepływu specjalistów, tworzenia wspólnych platform o charakterze edukacyjnym i badawczym). W integracji państw etap ten oznacza kształtowanie się jednolitego rynku wewnętrznego. W odniesieniu do przedsiębiorstw chodzi o wyłanianie się czterech typów jednostek (filii ${ }^{7}$ ): handlowych, produkcyjnych, technologicznych i strategicznych. Najniżej rozwiniętą formą integracji są filie handlowe - ich celem jest sprzedaż dostarczanych z zewnątrz produktów oraz budowanie/umacnianie pozytywnego wizerunku/marki na rynku zagranicznym. Filie produkcyjne (montownie, zakłady dostarczające podzespoły/komponenty, samodzielne fabryki produkujące gotowe wyroby od podstaw) mogą mieć różny zakres zaangażowania (obsługa wybranego regionu czy części procesu produkcyjnego dla całego systemu). Filie technologiczne mają charakter kreatywny - to miejsca tworzenia nowych rozwiązań, które służą „wyłapywaniu impulsów” (np. specyfik regionu) oraz transformowaniu ich w gotowe rozwiązania innowacyjne.

${ }^{7} \mathrm{~W}$ tym przypadku określenie „filia” nie musi oznaczać 100\% własności przedsiębiorstwa, może to być np. joint venture oparte na wykorzystywaniu zdolności dystrybucyjnych lokalnego partnera. 
W przypadku, gdy mamy do czynienia z ośrodkiem realizującym równocześnie wszystkie typy aktywności (produkcja, handel, działalność B+R, finansowanie), filia ma charakter strategiczny.

$\mathrm{Na}$ etapie „wspólnego rynku” niejako naturalnie następuje wyłonienie obszarów kluczowych dla integrujących się podmiotów (działów) oraz wskazanie głównych ośrodków ogniskowania się regionalnych różnic (dywizje geograficzne). W konsekwencji kolejnym krokiem jest powołanie komórek koordynacyjnych, mających zapewnić ,zgranie” systemu - odpowiednik unii ekonomicznej. Orchestratorami procesu (Brown, Davidsson, Wiklund 2001: 953-968) stają się zwykle podmioty wiodące, dysponujące największym potencjałem, zdolne do ustalenia struktury „centrów decyzyjnych” sieci - centrów kompetencji wyznaczających standardy, harmonogram, metody implementacji strategii budowania unii ekonomicznej. Wyłonienie orchestratora stanowi naturalną konsekwencję makropozycji podmiotu, która jest miarą konkurencyjności systemowej, będącej realizacją koncepcji współtworzenia wartości organizacji przez wielu interesariuszy (Esser et al. 1996; Kotler, Kartajaya, Seitawan 2010: 19-46).

W toku procesu integracyjnego mogą pojawić się sfery, w których pewna grupa elementów ,ugrupowania” wykazuje nadprzeciętną zbieżność celów. W przypadku państw przykładem jest przyjęcie wspólnej waluty. W odniesieniu do sieci biznesowych podobnie można interpretować włączanie wcześniej samodzielnych elementów pod parasol jednej marki. W obu sytuacjach konieczne jest najpierw spełnienie odpowiednich kryteriów konwergencji, a następnie dbanie o „wspólne dobro", którym jest marka firmowa. Konieczne jest podporządkowywanie się restrykcyjnym wymogom odnośnie do zasad realizacji „,wspólnej polityki gospodarczej”. Przedsiębiorstwa posługujące się jednolitą marką muszą mieć świadomość odpowiedzialności za utrzymanie jej wartości - przyjmują zobowiązanie do dotrzymywania standardów jakości. Włączanie nowych podmiotów do ,strefy marki firmowej" wymaga przyjęcia przez nowych członków zobowiązania do należytej staranności w realizacji polityki wewnętrznej.

Unia walutowa nie musi jednak oznaczać wprowadzenia wspólnej waluty (marki), ale wiąże się z usztywnieniem kursów wymiany walut jej państw członkowskich (wskazanie miejsca marki w systemie). Odpowiednia interpretacja tego poziomu integracji dla przedsiębiorstw oznacza, że marki, należące do poszczególnych członków sieci biznesowej zostają uporządkowane względem siebie - następuje ustalenie portfela marek z podziałem na obsługiwane segmenty. Potencjał poszczególnych segmentów będzie z kolei wyznaczał miejsca odpowiedzialnych za marki podmiotów w strukturze organizacyjnej sieci (tak jak siła gospodarki wyznacza pozycję danego państwa w procesach decyzyjnych w strefie euro).

Ostatecznie w wyniku postępującego procesu integracyjnego dochodzi do wykrystalizowania się organizmów/systemów biznesowych, będącym odpowiednikiem ugrupowań integracyjnych. Stwierdzenie to oparte jest na dostrzeżeniu siły oddziaływania GSB (tak jak np. UE) na uwarunkowania funkcjonowania innych 
podmiotów (w tym jej członków). Efektem postępującego procesu integracyjnego jest bowiem konsolidacja mniejszych podmiotów wokół liderów regionalnych i branżowych, co prowadzi do oligopolizacji przestrzeni globalnej. Najwyższy poziom integracji - unia polityczna - oznacza zatem budowanie relacji, które wymagają zrozumienia:

- idei kooperencji i społecznej odpowiedzialności - równoczesnej współpracy i konkurencji (Zineldin 2004; Cygler 2007: 63-64) oraz uwzględniania interesów wszystkich stakeholders - budowania wartości społeczno-ekonomicznej (creating shared value) (Porter, Kramer 2011: 62-77);

- zasad modelu regulacyjnego - dobrowolnej, częściowej rezygnacji z własnej suwerenności w celu włączenia się w struktury jednego z głównych graczy/ oligopolistów - ugrupowania, sieci biznesowej (Thomson et al. 1991: 271);

- wyzwań kongruencji - konieczności działania między rynkiem a hierarchią, czyli kreowania sieci, wykorzystywania struktur mieszanych/kooperacyjnych jako formy realizacji procesów rynkowych adekwatnych do współczesnych wyzwań; paradygmat KKK (Sulejewicz 1997: 192-194)

Współpraca na tym poziomie, z uwagi na siłę i rozległość oddziaływania „układających się stron”, kreuje nowy model przywództwa - orchestratorów, łączących cechy charyzmatycznego lidera, sprawnego koordynatora i profesjonalnego dyrygenta-wituoza ${ }^{8}$. Specyfika realizacji strategii konkurencyjnej przez orchestratora wymaga wykazania się zdolnością do rezygnacji z partykularnych interesów lidera na rzecz długookresowej spójności i zrównoważonego rozwoju całego systemu (ugrupowania, sieci) - przeniesienie decyzji dotyczących strategii „politycznej” na poziom ponadnarodowych, kolegialnych instytucji. Fundamentem tego etapu jest konstytuowanie sprawnego systemu dzielenia się wiedzą, władzą i odpowiedzialnością jako mechanizmu prorozwojowych zmian organizacji, dostosowujących je do wymogów dynamicznego otoczenia.

Konkludując - podjęcie działań integracyjnych to reakcja uczestników rynku na wyzwania stawiane przez otoczenie. Odpowiedzią na wymagania obecnej fazy globalizacji (korporacyjnej) jest zagęszczająca się sieć możliwych powiązań organizacyjnych o charakterze ponadnarodowym, w tym między wiodącymi przedstawicielami gospodarki światowej. Kluczową kwestią, na którą należy zwrócić uwagę, jest nowy typ relacji między konkurentami (kooperencja). Podmioty koncentrują się na zabieganiu o rozbudowę swoich stref wpływów, dzięki doskonaleniu własnych, kluczowych kompetencji w ramach zintegrowanego systemu współpracy - zdolności konkurencyjnych pozwalających na efektywne wykorzystanie możliwości stwarzanych przez globalną przestrzeń biznesową.

\footnotetext{
${ }^{8}$ Podobną koncepcję prezentuje paradygmat przedsiębiorczości według H. H. Stevensona. Przedstawione przez autora trzy formy postaw - promotora, menedżera, zarządcy - można przypisać wskazanym cechom orchestratora.
} 


\section{INTERPRETACJA MODELU INTEGRACJI BIZNESOWEJ - CASE STUDIES}

Podsumowanie opracowania stanowią przykłady realizacji modelu integracji biznesowej w praktyce - case studies dla następujących firm: Volkswagen (motoryzacja, Niemcy), Pfizer (farmacja, Stany Zjednoczone) oraz British Petroleum (petrochemia, Wielka Brytania).

Analizując historię ekspansji poszczególnych przedsiębiorstw na rynku międzynarodowym, starano się wskazać etapy rozwojowe odpowiadające poszczególnym fazom modelu integracji biznesowej. Oczywiste jest, że nie w każdym przypadku zaistniała możliwość precyzyjnego przedstawienia wszystkich cech/zjawisk opisywanych w ujęciu teoretycznym. Skoncentrowano się zatem na wybranych/kluczowych elementach charakteryzujących daną fazę (tab. 2).

Kluczowe cechy poszczególnych etapów integracji biznesowej

\begin{tabular}{|c|l|}
\hline Etap & \multicolumn{1}{|c|}{ Opis działań koniecznych dla realizacji etapu } \\
\hline I & $\begin{array}{l}\text { Umowy o współpracy - w ramach lańcucha produkcyjnego: } \\
\text { - początek działalności - pierwsze działania integracyjne, } \\
- \text { umacnianie na lokalnym rynku - zwykle zasięg narodowy }\end{array}$ \\
\hline II & $\begin{array}{l}\text { Oligopolizacja „regionalna” w branży: } \\
\text { - regionalna (narodowa) i branżowa, } \\
\text { - ekspansja na inne kontynenty (internacjonalizacja struktur) }\end{array}$ \\
\hline III & $\begin{array}{l}\text { Ksztaltowanie jednolitej polityki sieci: } \\
- \text { ukształtowanie wiodących działów (produktowych), } \\
- \text { ukształtowanie wiodących sfer ,,geograficznych” (dywizje kontynentalne), } \\
- \text { ustanawianie czterech typów filii (produkcyjnych, handlowo-usługowych, } \\
\text { technologicznych, strategicznych) }\end{array}$ \\
\hline IV & $\begin{array}{l}\text { Specjalizacja i globalna koordynacja systemu: } \\
- \text { fuzje i przejęcia, alianse strategiczne, inne umowy, } \\
- \text { centra kompetencji sieci, mechanizmy koordynacji }\end{array}$ \\
\hline V & $\begin{array}{l}\text { Standardy obsługi klienta - segmenty rynku globalnego: } \\
- \text { globalna marka firmowa - rebranding, ,wchłanianie”, } \\
- \text { portfel marek - paleta marek indywidualnych }\end{array}$ \\
\hline VI & $\begin{array}{l}\text { Mechanizm regulacji - system ,gospodarczo-polityczny” : } \\
- \text { orchestrator - rankingi potwierdzające pozycję, cechy, } \\
- \text { kooperencja - współpraca z bezpośrednimi konkurentami }\end{array}$ \\
\hline
\end{tabular}

Źródło: opracowanie własne. 


\subsection{Case study nr 1 - przypadek etapowego kreowania GSB Volkswagen}

Analiza systemu powiązań w ramach istniejącej obecnie GSB Volkswagen (VW) pozwala stwierdzić, że proces jej kreowania przebiegał w rytm modelu integracji biznesowej. Do końca lat 60. XX w. VW działał na rzecz wypracowania swojej pozycji na rynku lokalnym (niemieckim), m.in. podpisując umowy o współpracy ${ }^{9}$. Kolejny etap to przygotowywanie się do pełnego wyjścia na rynek międzynarodowy - kooperacja ze stałymi dostawcami, mniejszymi producentami (konsolidacja łańcuchów produkcyjnych oraz podział rynku na strefy wpływów). Pozycję oligopolisty ugruntował zakup od Daimlera marki Audi (wejście do grona liderów, obok BMW i Daimlera). Lata 70. XX w. to kształtowanie się oligopolu ogólnoeuropejskiego - wejście przedsiębiorstw np. francuskich, hiszpańskich. VW integrował wówczas sieć poprzez joint venture z podmiotami branży. Początkowo na bliskich kulturowo i geograficznie rynkach (etap II) - wypracowywanie wspólnych wzorców (modeli). W latach 80. oraz 90. XX w. sieć VW weszła w fazę budowy wspólnego rynku (etap III). Umowy o współpracy zostały pogłębione, nastąpiły zakupy udziałów: 1977 r. - nabycie 75\% udziałów w Chrystler Motors w Brazylii; 1980 r. przejęcie Chrysler Fevre Argentina S.A.I.C; 1985 r. - zakup 50\% udziałów w Shanghai Tractor \& Automobile Corporation w Chinach; 1986 r. - przejęcie 51\% udziałów w hiszpańskim SEAT; 1991 r. - przejęcie 31\% akcji czeskiej firmy ŠKODA, automobilová a.s; 1991 r. - zakup 80\% akcji Bratislavské Automobilové Závody; 1993 r. - przejęcie FSR Tarpan (Polska).

Systematycznie kształtowała się wspólna polityka handlowa produktu - klasy produktów, rynki obsługiwane przez uczestników sieci VW. Specjalizacja ta doprowadziła do wykreowania wiodących działów sieci jako kilku sfer aktywności o charakterze priorytetowym. Uczestnicy sieci (wcześniej samodzielne przedsiębiorstwa, zwykle działające tylko lokalnie) stawali się ogniwami systemu międzynarodowego - stabilizacja i intensyfikacja powiązań, ustanawianie czterech typów filii: produkcyjne (montownie, zakłady wyspecjalizowane), dystrybucyjne (handlowo-usługowe), technologiczne (kreujące wzorce, modele, desingnerskie) oraz strategiczne (decydujące o kierunkach rozwoju danego obszaru sieci). W ten sposób uczestnicy sieci zajęli swoje pozycje na rynku międzynarodowym. W kolejnej fazie kapitalne znaczenie miało stworzenie mechanizmów koordynacji sieci - powołanie komórek strategicznych, których zadaniem było stymulowanie procesów kreacji wartości dodanej na bazie istniejącego łańcucha produkcyjnego (etap IV).

Etap V realizowany jest w sieci VW jako ustalenie portfela marek z podziałem na obsługiwane segmenty rynku, w tym z dbałością o unikanie „kanibalizacji” produktów (np. ograniczenia dla Škody Superb „zjadającej” segment VW).

${ }^{9}$ Na przykład 1965 r. przejęcie od koncernu Daimler-Benz firmy Auto Union - udziały 50,3\%, następnie systematyczne pogłębianie współpracy (1969 r. wzrost udziałów do 59,5\%, a w 2009 r. $99,55 \%)$. 
Stworzona GSB Volkswagen stanowi swoisty „holding motoryzacyjny”, skupia niezmiernie zróżnicowane przedsiębiorstwa - Audi, Bugatti, Bentley, Lamborghini, Porsche, Škoda, VW, SEAT, Scania, MAN, a dodatkowo dziesiątki mniejszych, mniej znanych dostawców konkretnych części i podzespołów. Każde z przedsiębiorstw sieci realizuje swoją strategię w ramach systemu GSB VW (Group Values and Model of Suitable Development ${ }^{10}$ ) - efekt dobrowolnej rezygnacji z części swojej suwerenności na rzecz globalnej efektywności (etap VI).

Konkludując, przedstawione case study dla GSB Volkswagen także potwierdza, że włączając się w globalny system budowania konkurencyjności pod przywództwem jednego z liderów branżowych uczestnicy mogą realizować swoje strategie - równocześnie zyskując wskazówki dotyczące tego, jak najefektywniej działać pod presją międzynarodowej konkurencji.

\subsection{Case study nr 2 - przypadek etapowego kreowania Pfizer}

Pfizer Inc. to jeden z liderów światowego sektora farmaceutycznego, międzynarodowy koncern z siedzibą w Nowym Jorku, założony w 1849 r. W początkowym okresie działalność firmy koncentrowała się na rynku lokalnym. Wykorzystywała posiadany potencjał dla rozwoju i umacniania pozycji narodowego lidera (m.in. dzięki zasobom pozwalającym na wytwarzanie kwasu askorbinowego - witaminy C oraz penicyliny). Pierwszym przejawem ekspansji kapitałowej było wejście na giełdę nowojorską (1944). W 1961 r. Pfizer dokonał pierwszej reorganizacji struktur, przenosząc siedzibę z Brooklynu na Manhattan i otwierając centrum badań naukowych w Groton w stanie Connecticut. Stanowiło to jeden z elementów umacniania pozycji regionalnego lidera, który chce narzucać swoje wzorce współpracującym podmiotom. Kolejnym krokiem było (1970) wyjście na rynki zagraniczne (oddziały firmy i laboratoria naukowe poza granicami USA). Działania te stanowią przykłady posunięć w ramach etapu I i II.

$\mathrm{W}$ połowie lat 90 . XX w. korporacja podjęła się uporządkowania swojej aktywności w ramach obszarów kluczowych kompetencji i sfer geograficznego zaangażowania - dostosowanie strategii do różnych obszarów działalności korporacji: w Europie i Stanach Zjednoczonych ukierunkowana na leczenie chorób związanych ze starzeniem się i niezdrowym trybem życia (otyłość, problemy $\mathrm{z}$ cholesterolem), natomiast w Afryce koncentracja na leczeniu malarii, cholery, AIDS. Systematyczne ustanawianie kolejnych filii wszystkich typów: przedstawicielstwa handlowe (w 150 krajach, np. w Polsce, Kanadzie, Australii, Japonii, Namibii), fabryki produkcyjne (ponad 70 fabryk, np. w USA, Brazylii, Meksyku, Turcji, Słowenii, we Włoszech, w Australii, Japonii, Belgii), jednostki badawcze

${ }^{10}$ Budowanie wartości sieci i model zrównoważonego nią zarządzania według Koncernstrategie 2015 obejmuje pięć sfer: klienci i rynek, innowacje, efektywność (praca, czas, wiedza), orientacja na wartość, atrakcyjność miejsca pracy. 
- Groton (CT, USA), Sandwich (Wielka Brytania), La Jolla (CA, USA), St. Louis (MO, USA), Cambridge (MA, USA), Rinat (CA, USA). Za odpowiednik filii strategicznej można uznać koncentrację jednostek korporacji w rejonie wschodniego wybrzeża w megalopolis „BosWash”, które obejmuje miasta: Boston, Hartford, Nowy Jork, Filadelfię, Baltimore i Waszyngton. W ten sposób Pfizer realizował wymogi III etapu integracji biznesowej.

Przełomowym momentem w budowaniu sieci w kolejnej fazie - unii ekonomicznej - były trzy fuzje o znaczeniu strategicznym: $2000 \mathrm{r}$ - przejęcie aktywów Warner-Lambert (wartość 87 mld USD), 2003 r. - przejęcie korporacji Pharmacia (wartość 57 mld USD) oraz 2009 r. - korporacji Wyeth (wartość 68 mld USD ${ }^{11}$ ). Ponadto Pfizer stale prowadził działania na rzecz rozszerzenia aktywności na nowe perspektywiczne kategorie biznesu farmaceutycznego, np. leki OTC - przejęcie za 3,5 mld USD King Pharmaceuticals (2010 r.) czy Ferrosan (2011 r.), a także nowe rynki - np. joint venture (2012 r.) Pfizer China's Zhejiang Hisun Pharmaceutical Co. (kapitał 250 mln USD, udziały: Pfizer 49\%, Hisun 51\%). Podejmował też działania służące poprawie jakości oraz efektywności, np. alians technologiczny z Parexel International Corp. (2011 r.) czy umowa dotycząca usług logistycznych z Fiege (2011 r.). W wyniku tych przedsięwzięć Pfizer Inc. umocnił swoją pozycję jako jeden z oligopolistów globalnego rynku farmaceutycznego, który sprawnie koordynuje działania zbudowanej sieci - etap IV.

Pozycję Pfizera potwierdzają wszystkie rankingi (np. 2012 r., poz. 37. Forbes Global 2000 z wartością rynkową ponad 200 mld USD). Nie znajdziemy jednak marki Pfizer w rankingu 100 najcenniejszych marek świata - wynika to z faktu, że na tym rynku skuteczniejsza jest strategia indywidualizacji oferty dla poszczególnych segmentów (specjalności medycznych). Stąd kapitał marki w branży farmaceutycznej tworzą silne marki indywidualne, wspierane jedynie nazwą firmy. W konsekwencji wypełnienie wymogów etapu $\mathrm{V}$ to wypracowanie takich marek, jak np. Viagra, Visine, Nicorette, Ben-Gay, Xanax, Zyrtec, które stanowią wręcz synonimy opisu leków na daną dolegliwość. W ten sposób Pfizer systematycznie udowadnia swoją pozycję na rynku poprzez kolejne, coraz bardziej rentowne produkty, co potwierdza jego rekomendację na orchestratora sieci.

Zasada współodpowiedzialności za rozwiązywanie problemów globalnych (społecznej odpowiedzialności) zobrazowana jest w zapisach określających misję firmy, takich jak: „zastosowanie innowacji naukowych w celu poprawy zdrowia na świecie”, ,pracujemy razem, by tworzyć zdrowszy świat, [...] przekraczając granice organizacyjne i geograficzne w celu sprostania różnorodnym oczekiwaniom naszych klientów”, „wychodzimy naprzeciw potrzebom i oczekiwaniom

${ }^{11}$ Przy transakcji Pfizer zmuszony był do współpracy z konsorcjum bankowym utworzonym przez: Bank of America, Barclays, Citigroup, Goldman Sachs i JP Morgan Chale - kredyt o wysokości 22,5 mld USD. 
naszych klientów wewnętrznych i zewnętrznych, przywiązując szczególną wagę do ich satysfakcji ze współpracy". Pfizer prowadzi zatem np. edukację zdrowotną w krajach Trzeciego Świata (Afryka, kraje azjatyckie i Ameryki Łacińskiej) w celu zapobiegania rozprzestrzenianiu się chorób zakaźnych czy na rzecz zmniejszenia umieralności niemowląt. Urzeczywistnia zapisy misji w praktyce biznesowej poprzez kooperencję, np. dążenie do ograniczenia kosztów ponoszonych na badania - współpraca z bezpośrednim konkurentem, czyli GlaxoSmithKline ${ }^{12}$. Obecnie firma kładzie nacisk na innowacyjność, ale stara się o stałą poprawę wyników (jak sama deklaruje), „starannie je mierząc i dbając o to, aby nigdy nie działo się to kosztem człowieka". Dotyczy to również interesariuszy wewnętrznych - pracowników ${ }^{13}$. W konsekwencji można ją uznać za godną miana orchestratora sieci - etap VI.

Konkludując, przez 165 lat działalności z małej firmy Pfizer stał się silną globalną korporacją. W świetle powyższej analizy uzasadnione wydaje się stwierdzenie, że jest to efektem wykorzystania modelu systematycznego nadbudowywania potencjału rozwojowego w procesie integracji biznesowej.

\subsection{Case study nr 3 - przypadek etapowego kreowania GSB British Petroleum}

Analiza procesu kształtowania się GSB British Petroleum (BP) ma na celu wskazanie, że w modelach wdrażania koncepcji integracji biznesowej w różnych sektorach występują oczywiste różnice, lecz równocześnie sama idea pozostaje niezmienna. Etap I rozwoju GSB BP to budowanie „lokalnej” pozycji w ramach imperium wpływów brytyjskich: 1909 r. - założenie Anglo-Persian Oil Company (później Anglo-Iranian), 1934 r. - joint venture Anglo-Iranian Oil Corporation („,baza” późniejszego BP) z Kuwait Oil Company; 1954 r. - konsorcjum Anglo-Iranian Oil Company oraz Standard Oil Indiana (Amoco); 1969 r. - zakup 25\% udziałów Standard Oil Company of Ohio (Sohio). Etap II to podjęcie walki o pozycję globalnego oligopolisty: przejęcie Amoco (1998 r.), Burmah Castrol i Atlantic Richfield Company $\left(2000 \mathrm{r}^{14}\right)$, marki Aral $\left(2002 \mathrm{rr}^{15}\right)$ oraz liczne joint venture $\mathrm{z}$ podmiotami $\mathrm{z}$ branży.

${ }^{12}$ W 2009 r. firmy poinformowały o połączeniu swoich działów zajmujących się walką z HIV i utworzeniu joint venture ViiV Healthcare z siedzibą w Brentford (Wielka Brytania) - udziały: 85\% GSK, $15 \%$ Pfizer.

${ }^{13}$ Korporacja zajmuje 41. miejsce (na 150) wśród najlepszych pracodawców zatrudniających młodych wykształconych pracowników w USA. Pomaga to w budowie dobrych relacji z uczelniami i umacnia pozytywny wizerunek marki.

${ }^{14} 2000$ r. - połączenie BP Amoco z Atlantic Richfield Company (ARCO); wartość transakcji 26,8 mld USD.

152002 r. - przejęcie od Veba Oil marki Aral (sieć stacji benzynowych) - w lutym 51\% udziałów, w lipcu pozostałych 49\% (3,6 mld USD). 
Etap III to umacnianie poszczególnych obszarów sieci - rozproszone globalnie inwestycje, alianse (w tym joint venture). Specyfika sektora to silnie uzależnienie od warunków naturalnych (występowania złóż), co wzmaga konieczność integracji (w tym $\mathrm{z}$ bezpośrednimi konkurentami ${ }^{16}$ ). Należy podkreślić, że jest to proces stale trwający/otwarty. Kapitalne znaczenie ma jednak sposób doboru kooperantów - według określonych zasad współpracy. Oznacza to, że podmioty decydujące się na wejście do systemu są świadome znaczenia integracji dla poprawy efektywności swojej działalności, nawet kosztem częściowej utraty suwerenności.

Ważnym posunięciem integracyjnym na tym etapie (budowania jednolitego rynku - etap IV) jest badanie potencjału nowych obszarów - wyjście poza obszar wydobycia i handlu tradycyjnymi produktami petrochemicznymi. Za przedsięwzięcia przyszłościowe można uznać obszar odnawialnych źródeł energii, np. 2009 r. - zakup Orisol Corp Energetica SA (energia wiatrowa i słoneczna) czy współpraca z RGE Energy AG (energia słoneczna). Stanowi to dowód, że siłą napędową integracji jest globalizacja, która stawiając nowe wyzwania, wymusza uaktywnianie kolejnych sfer.

Obecnie GSB BP realizuje etap V i VI, czyli wykorzystuje siłę marki BP (przykłady: TNK-BP, rebranding Aral na BP) oraz organizuje współpracę na bazie strategiczne zorientowanego łańcucha tworzenia wartości (w tym poprzez kooperencję z Shell, Statoil, ExxonMobil, ConocoPhillips - konsorcjum benchmarkingowe).

Reasumując - przedstawione case study dla GSB BP pozwala pozytywnie zweryfikować tezę o wykorzystywaniu modelu integracji biznesowej jako wzorcowej ścieżki rozwoju globalnych sieci.

Zaprezentowany model integracji biznesowej uprawnia do konkluzji, iż rozwój globalnych sieci biznesowych obserwujemy we wszystkich sektorach gospodarki światowej. Powstawanie GSB następuje w konsekwencji realizacji przez poszczególne przedsiębiorstwa „własnych” strategii wykorzystywania otwierających się możliwości na rynku międzynarodowym. Integracja stanowi odpowiedź przedsiębiorstw na zmiany uwarunkowań rozwojowych, które wymuszają budowanie koalicji - etap globalizacji korporacyjnej. Kierunek i tempo rozbudowywania struktur poszczególnych GSB to wynik przewartościowań dokonujących się wraz z rozwojem procesu globalizacji - konieczność współpracy, glokalizacja, kooperencja, zrównoważony rozwój, wartość wspólna ${ }^{17}$ - w konkretnych obszarach geograficznych i branżowych.

${ }^{16}$ Na przykład 2003 r. - joint venture BP i rosyjskiego TNK, BP 50\%/TNK 50\%; 2005 r. - joint venture BP i Exxon, wspólna eksploracja złóż ThunderHorse, udziały BP 75\%/Exxon 25\%; 2005 r. - joint venture BP i Repsol YPF, wspólna eksploatacja złóż gazu, BP 70\%/YPF 30\%.

${ }^{17}$ Idea wartości wspólnej zrodziła się niejako w toku ewolucji uwarunkowań konkurencyjności w dobie globalizacji korporacyjnej. Sieć biznesowa jako koalicja tak różnych uczestników wymaga wielu kompromisów. 


\section{PODSUMOWANIE}

W artykule podjęto próbę wykazania, że postępująca globalizacja i liberalizacja wymusza stałe dostosowywanie się uczestników rynku do wymogów zmieniającego się otoczenia - ich odpowiedzią jest włączanie się w budowanie koalicji, systemów korporacyjnych jako układów zdolnych do sprostania pojawiającym się wyzwaniom. Analizy podporządkowano prezentacji i egzemplifikacji koncepcji modelu integracji biznesowej, wzorowanego na klasycznym modelu B. Balassy, który potraktowano jako formę uniwersalnego schematu rozwojowego. Starano się wykazać, że jest on wykorzystywany nie tylko przez państwa, lecz także przedsiębiorstwa. Efektem realizacji koncepcji jest systematyczne rozbudowywanie globalnych sieci biznesowych wokół najpotężniejszych korporacji (orchestratorów), podobnie jak ugrupowań integracyjnych wokół państw liderów. W celu udowodnienia postawionej tezy przywołano przykłady rozwoju sieci biznesowych Volkswagen, Pfizer, British Petroleum - korporacji transnarodowych pochodzących z różnych krajów i działających w odmiennych sektorach. Badanie historii rozwoju wskazanych sieci wykazało, że mimo pewnych różnic istota budowania powiązań pozostaje niezmienna - poprawa efektywności funkcjonowania $\mathrm{w}$ dynamicznie zmieniających się warunkach (postępującej globalizacji i liberalizacji). W świetle powyższego wydaje się, że można uznać przedstawioną koncepcję integracji biznesowej za spójny i przydatny model analityczny.

\section{BIBLIOGRAFIA}

Blomstermo A., Sharma D. (2003), Learning in the Internationalization Process of Firm, Edward Elgar Publishing, Cheltenham Northampton MA.

Brown T. E., Davidsson P., Wiklund J. (2001), An Operationalization of Stevenson's Conceptualization of Entrepreneurship as Opportunity - based Firm Behavior, "Strategic Management Journal", No. 22.

Budnikowski A. (2006), Międzynarodowe stosunki gospodarcze, PWE, Warszawa.

Cygler J. (2007), Kooperencja - nowy typ relacji między konkurentami, „Organizacja i Kierowanie”, nr 2.

Esser K., Hillebrand W., Messner D., Meyer-Stamer J. (1996), Systemic Competitiveness: New Governance Patterns for Industrial Development, Frank Cass, London 1996.

Flejterski S., Wahl P. T. (2003), Ekonomia globalna - synteza, Wydawnictwo Difin, Warszawa.

Fung V. K., Fung W. K., Wind Y. Jr. (2008), Konkurowanie w płaskim świecie. Budowanie przedsiębiorstw przystosowanych do płaskiego świata, Wydawnictwa Akademickie i Profesjonalne, Warszawa.

Gorynia M., Jankowska B. (2008), Klastry a międzynarodowa konkurencyjność i internacjonalizacja przedsiębiorstwa, Wydawnictwo Difin, Warszawa.

Gulati R., Nohria N., Zaheer A. (2000), Strategic Networks, „Strategic Management Journal”, Vol. 21. 
Hagel J., Brown J. S. (2005), The Only Sustainable Edge: Why Business Strategy Depends on Productive Friction and Dynamic Specialization, Harvard Business School Press, Boston.

Håkansson H., Snehota I. (1995), Developing Relationship in Business Networks, Routledge, London.

Huff A. S., Floyd S. W., Sherman H. D., Terjesen S. (2011), Zarzadzanie strategiczne. Podejście zasobowe, Wolters Kluwer Business, Warszawa.

Kotler Ph., Kartajaya H., Seitawan I. (2010), Marketing 3.0, Wydawnictwo MT Biznes, Warszawa.

Marzęda K. (2007), Proces globalizacji korporacyjnej, Oficyna Wydawnicza Branta, BydgoszczWarszawa-Lublin.

Mikołajczyk B., Kurczewska A., Fila J. (2011), Klastry na świecie. Studia przypadków, Wydawnictwo Difin, Warszawa.

Platonoff A. L. (2009), Zarządzanie dynamiczne, Difin, Warszawa.

Porter M. E. (1998), Clusters and Competition: New Agendas for Companies Governments and Institutions, [w:] M. E. Porter (ed.), On Competition, Harvard Business Review Book, Boston.

Porter M. E. (2001), Porter o konkurencji, PWE, Warszawa.

Porter M. E., Kramer M. R. (2011), The Big Idea: Creating Shared Value, "Harvard Business Review", No. 89 (1/2).

Pyke F., Sengenberger W. (1992), Industrial districts and local economic regeneration: Research and policy issues, [w:] F. Pyke, W. Sengenberger (eds.), Industrial Districts and Local Economic Regeneration, International Institute for Labour Studies, Geneva.

Robertson R. (1985), The Relativization of Societies: Modern Religion and Globalization, [w:] T. Robbins, W. Shepherd, J. McBride (eds.), Cults, Culture and the Law, Scholars Press, Chico CA.

Rosińska-Bukowska M. (2012), Rozwój globalnych sieci biznesowych jako strategia konkurencyjna korporacji transnarodowych, Wydawnictwo Uniwersytetu Łódzkiego, Łódź.

Scholte J. A. (2000), Globalization: A Critical Introduction, St. Martin's Press Inc., New York.

Skawińska E., Zalewski R. I. (2009), Klastry biznesowe w rozwoju konkurencyjności i innowacyjności regionów. Świat - Europa - Polska, PWE, Warszawa.

Stigliz J. E. (2004), Globalizacja, Wydawnictwo Naukowe PWN, Warszawa.

Sulejewicz A. (1997), Partnerstwo strategiczne: modelowanie wspótpracy przedsiębiorstw, „Monografie i Opracowania”, nr 427, Oficyna Wydawnicza SGH, Warszawa.

Thomson G., Frances J., Levacic R., Mitchell J. (1991), Markets, Hierarchies and Networks: The Co-ordination of Social Life, Sage Publications, London.

Wiedersheim-Paul F., Olson H. C., Welch L. S. (1978), Pre-Export Activity: The First Step in Internationalization, "Journal of International Business Studies" Vol. 9 (1).

Zineldin M. (2004), Co-operition: The Organisation of the Future, Marketing, "Intelligence and Planning”, Vol. 22.

Magdalena Rosińska-Bukowska

\section{THE MODEL OF ECONOMIC INTEGRATION AS A PATTERN OF INTEGRATION OF BUSINESS SYSTEMS - THE CONCEPT AND INTERPRETATION}

\footnotetext{
Abstract. The purpose of this article is to present the concept of business integration model, similar to the classic Balassa's model, as a form of development scheme, which is used not only by the state but also other actors - transnational corporations (TNCs). The article is divided into six
} 
parts. The first and second parts - the deepening of the integration process as a response participants of global market about the challenges of globalization and liberalization. The third part - the concept of business integration model (the genesis, the concept, elements). The fourth part - the interpretation of business integration model (theoretical background with using several economic theories) The fifth and sixth parts - the implementation of business integration model in practice. The author shows case studies for Volkswagen (automotiv, Germany), Pfizer (pharmaceutical, USA) and British Petroleum (petrochemical, United Kingdom).

Keywords: integration, business, globalization, corporations, business systems. 